This article was downloaded by: [New York University] On: 13 August 2013, At: 12:34

Publisher: Routledge

Informa Ltd Registered in England and Wales Registered Number: 1072954 Registered office: Mortimer House, 37-41 Mortimer Street, London W1T 3J H, UK

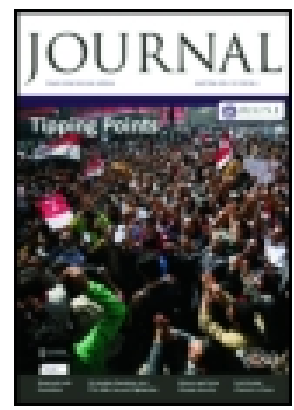

Royal United Services Institution. J ournal

Publication details, including instructions for authors and subscription information: http:// www. tandfonline.com/ loi/rusi 19

\title{
The Telephone and Its Application to Military and Naval Purposes
}

W. H. Preece

Published online: 11 Sep 2009.

To cite this article: W. H. Preece (1878) The Telephone and Its Application to Military and Naval Purposes, Royal United Services Institution. J ournal, 22:94, 209-218

To link to this article: http://

dx. doi.org/ 10.1080/03071847809416343

Taylor \& Francis makes every effort to ensure the accuracy of all the information (the "Content") contained in the publications on our platform. However, Taylor \& Francis, our agents, and our licensors make no representations or warranties whatsoever as to the accuracy, completeness, or suitability for any purpose of the Content. Any opinions 
and views expressed in this publication are the opinions and views of the authors, and are not the views of or endorsed by Taylor \& Francis. The accuracy of the Content should not be relied upon and should be independently verified with primary sources of information. Taylor and Francis shall not be liable for any losses, actions, claims, proceedings, demands, costs, expenses, damages, and other liabilities whatsoever or howsoever caused arising directly or indirectly in connection with, in relation to or arising out of the use of the Content.

This article may be used for research, teaching, and private study purposes. Any substantial or systematic reproduction, redistribution, reselling, loan, sub-licensing, systematic supply, or distribution in any form to anyone is expressly forbidden. Terms \& Conditions of access and use can be found at http://www.tandfonline.com/page/terms-andconditions 


\section{LECT URE.}

Friday, 21st December, 1877.

Lieut:-General Sir DANIEL LYSSONS, K.C.B., Qua General, in the Chair.

\section{THE TELEPHONE AND ITS APPLICAIION TO I AND NATAL PURPOSES.}

By W. H. Preece, Vice-President Society Telegraph Eng Member Institution Civil Engineers.

No one can deny the enormous ralue of the electric telegra like purposes. It has well nigh revolutionized the art of 7 becomo a great weapon of offence, as well as a great shield Operations that were a fow years ago impossible are now essential. The strategist in his office can now grasp a cont combinations. The actual manoeurres of armies can be cor directed like the toy figures of the game of Iriegs-spiel. tenance of the lines of tolegraph to an army in the tield is a as that of the more material lines of communication. The in fact, has become a necessity of the age. No war cor undertaken without its aid.

But it is not only in annihilating space, and bringing mental riew of the master mind $a$ dozen armies and $\Omega y$ that telegraphy is so valuable; it is in the rapid commr intelligence and orders to and from the Commanding Offic limb of cach army, howerer small; it is in connecting 1 immediato communication, the different parts of a fort entrenched camp, however much they may be scattered; it taining an uninterrupted conncction between all parts of furce, however oxtensive may bo tho lines of circumvaliatio so serviecable. It would hare been impossible to bave kept o of Paris and Hetz without it. Indeed, it has a civilizing ir it not only tends to shorten the duration of war, but to d loss of life, by rendering possible those combinations wl cases of Sedan as well as of Metz, swallowed up temporai two great armies. Morcorer, it facilitates the supply VOL. XXII. 
regulates the traffic on railways, it aids the transport home of and wounded, it satisfies the craving for news, and it alleriate at home. It is well known that the Germans, guided by thei ence of 1866 , commenced the war of 1870 with a rery well c and extensive system of telegraphs for field service, but French had a system wanting in efficient organization and, deficient in men and material. Wo know little of the present system, excepting the fact that by its aid the army aroun maintrined its bear-like hug on the cloomed fortress, and $\mathrm{c}$ to thwart, with overpowering force, the tiger-like rash c Pasha.

So important is efficient telegraphy now considered for tl Army that 6 officers and 160 men are being trained and mair efficiency in the British postal telegraph system, so as to be in time of war. They are, in fact, daily rehearsing that $p$ they may hare some day to perform in earnest in an enemy'? Tloreover, we have our ficld telegraphs in constant training shot, Chatham, and elsewhere, though it is rery doubtful wh department has been nenrly sufficiently dereloped, or is angi being properly equipped, for such an army as ours, $H$ an here, not to criticise or describe the equipment of ou telegraphic system, but to describe an apparatus which ma most useful and raluablo adjunct to tho already well matur of waggons and barrows and cables in actual use. I mu distinction. between the permanent telegraphic ssstem of $\mathrm{tr}$ oceupied by an arm5, the semi-permanent lines of telegra] connect head-quarters, as it adrances; with this system, and t] "line" or temporary system of field telegraphs which $\mathrm{fc}$ morements of the various corps in the field, and maintains 1 munication with hend-quarters. The first two must neec worked on the ordinary telegraphic system in use, mair technical skilled labour, and worked by well trained, e: telegraphists. The flying line need not necessarily bo so me There is also the visual system, intended for outpost and rec duties, and which necessarily must be continued under circ which render field telegrnphs impractical. I do not intend this admirable system.

At present, the apparatus in use for field telegraphy is th Morse recording apparatus, which records its messages in tl dot and dash alphabet, understood only by the initiated, sut by a sounding instrument, which appcals, by a similar fc guage, to the car. Thus, to conrey intelligence from on another, a message has to be written down on paper, it has translated by a telegrapher into the Morse language, which re-translated at the distant end into the ordinary written lan then read by the recipient. These operations are subject to hare not secured faith in their reliability. Is thero any $\mathrm{Co}$ Officer here present who would not wish such an uncertain รery warm place? Those who were present at the Autumn I on Salisbury Plain know how to value its serrices. It is unq 
that the telegraph has not inspired confidence, and this is $d$ to its natural uncertainty as to the want of knowledge of $t$ is used. Acenracy in the transmission of orders is the sine a military telegraph. Wo know of one great disaster that a mistake. "Some one has blundered." It was the very determined upon in our late Ashantec War, and the rapid materials drawn from the Post Office stores were dispat, last moment, by passenger train, and stored in the office room. Yet we have the authority of Sir Lintorn Simmon that the operations in that war could not havo been carriec wore without its assistance, and that it was productive of economy to this country by shortening the expedition as the greatest amount of benefit to be derived from the $\mathrm{m}$ : means that were placed at the disposal of the General in $c$

Nor, the telephone, if it prove a practical instrumenl in the hand of every officer an instrument which will 1 actual words and tones of his orm voice to his correspor reasonable distance. I have spoken distinctly, at various to ninety miles; last week I spoke from Holyhead with $\mathrm{m}$ Dublin, through the cable joining those two places, and I able to recognise, with absoluto certainty, the roices people at sixty-soren miles. It will solro the moot questi best form of instrument for military telegraphs, about wh much diversity of opinion.

How is it that the human roice itself can be reprodr distances? When I strike a bell, blow a whistle, so clap my hands, or speak to you, how is it that these difl tions are conveyed through your ears so as to produce that sensation which is ealled sound? The air itself, $j$ breathe and more and have our boing, is a bighly elas which readily receires and tiansmits any motion imparted I clap my liands, I suddenly throw this air into motio formed, just like a stone thrown into water goneintes : circles round and round, striking and enveloping every course. This air-wave likewise enrelops everything in it impinging upon the tympana of four ears, it thero affect in such a way as to convey to tho brain that sensation whi lias taught us to be that sound due to the clapping of han therefore simply the undulations of the air; but there $i$ sound: I shake this box of nails; it makes a most disagree: blow this reed; it makes a soft musical tone. Why hare case noise and in the other mutsic? In the one case the each other in irregular spasmodic fashion, shivering the $\mathrm{dr}$ with unpleasant shocks; in the other ease the waves follo regularly, periodically, and rythmically, blending togi drum of the ear with pleasant sensations. Let us ignc confine ourselves to this musical instrument. I blow a were possible to illuminate a tube of air between the $\mathrm{x}$ instrument and any one of jour cars, you would see t1 and monlded into the most benutiful and regnlar: und 
rises and falls, like the vertical waves of the sea, but conde and rarefactions-close order and open order-moro like a barley in autumn time responding to the motion of a gentle br we conceive a line of particles to bo arranged along this tub long file of men or $n$ row of marbles, then if each particle excursion to and fro for the samo distance (the same am? Lowrever small, then if the motion of each particle bo succes: not simultaneous, the lino will bo excited into wares or : vibrations, as shown in Fig. 1 .

FIG. 1.

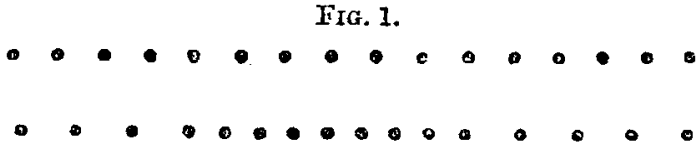

Now, let us fix our attention upon this musical instrument suppositions tube of air. I can produce various notes. C differs from another note only in the number of waves or vibrations produced per second. Middle $\mathrm{C}$ of the piano mak these vibrations, E $330, \mathrm{~F} 352, \mathrm{~A} 440$, and the octare to $\mathrm{C}$ second. The lowest note that can be heard by the hnman complete ribratious per second ; the highest, 38,000 . The the human voice is between 65 and 1,044 sonorous vibrat second. Thenever and however wo produce air vibrations, each other regularly between these two limits, we have not, one note differs from another note in its pitch, which is the $\mathrm{n}$ its sonorous vibrations per second. Bnt these notes may bo gentle or rough and loud.' Hence notes differ, not ouly in th but they differ in their loulness. Loudness depends upon th of the source of sound and upon the amplitude of the co vibrations of the particles of air. If I blow gently, the exc and fro is small. If I blow fiercely, the excursion to and fro The former undulations strike the ear gently, and the sen low; the latter strike it fiercely, and the sensation is lond. take three or four different instruments and I sound the sami each with the same force. The pitch is the same, the loudnc same, but there is no mistaking their difference. This diff called their quality, clang-tint, or timbre. Now, what ca clang-tint? I must beg your attention here, for here lies the the new articulating telephone.' This clang-tint is duo to the the wave of air. It is very difficult to conceive a differenc form of a wave of air. It is simple enough when we rega We see this for ourselves upon the surface of a pond or of th deep. But the difference of an air-wave lies, not in its ge form so much as in the rate of motion of its different par ware my hand backwards and forwards regularly or irregu can makle it move at any given rate, at any given time, anc the number of excursions and the amplitudo of cxcursion $t$ per unit of time may be the same, I can vary the form or ro corsion at will. This produces difference of quality, and th 
middlo $\mathrm{C}$, sounded on a piano, on a harp, on a bugle, or 1 is tho snmo note, but differing so much in clang-tint. It is to picture in the mind the beauty and minuteness of the so The ear, though approached by a channel the diameter quill, will receive the vibrations from a hundred voices : ments and can separate each by attention. Hence we ar first proposition, that sound is due to the undulations of $t$ that, as these undulations vary in number per second, in am] in form, so we have noise or music, varying in pitch, in lor in clang-tint.

Wo havo now to consider how we can catch up, as it sounds, and convey them into sometling else. It is said th could sound a note so deep and loud that he conld cracti Whenever anyone sings in a room, something can be alwa: rattle. If you open the piano, and sound the rorrels on notes, fou will hear the piano repeat them. Hence wo les air vilurations can be imparted to other grosser matter in $I$ hold before my mouth this dise of parchment-a small It responds to the tones of my voice. I can make this evic It is so constructed that it makes and breaks an electric cu time it vibrates. This electric current operates as an elec The elcetro-magnet actuates an armature. If the moti armature are of the same number as the dise, we shall ha repeated. There you are. Every noto I direct upon the peated by the magnet. But I cannot vary this note. shout or whether I hum; whether I sound the note upor ment or upon a tuning-fork, the noto given out by the $\mathrm{m}$ : same. It raries only in pitch, and not in loudness or in This is the first telephone ever made, that of liess of Frie and it is illustrated in Fig. 2.

Fis. 2.

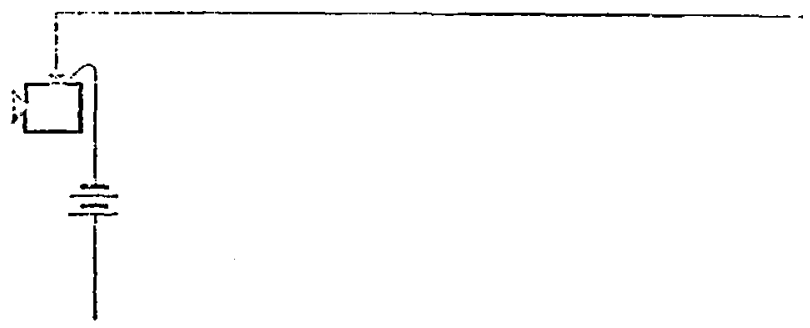

Now I must make a temporary diversion into the clectricity.

There are many ways of producing electricity. Wo hav a battery where the electricity was produeed by the ehemi position or combustion of zine, just as heat is produced by cal decomposition or combustion of coal. We can produce $i$ or by heat, but ono very common mode is to produce it by of a coil of wire in the neighbourhood of a permanent 
vice vers $\hat{d}$, by the motion of a magnet near a coil of wire. an ordinary shocking coil is made. Here is a large perman and here is a coil of wire. I saddenly more that coil current is produced, and I have rung a bell. But eren if 1 be fixed and the coil be fixed, any variation in the stren magnetism about that coil will produce a current of electri coil. Thus if in front of that magnet which has a coil $f$ pole, I move this mass of iron, a current will be produc

Fía. 3.

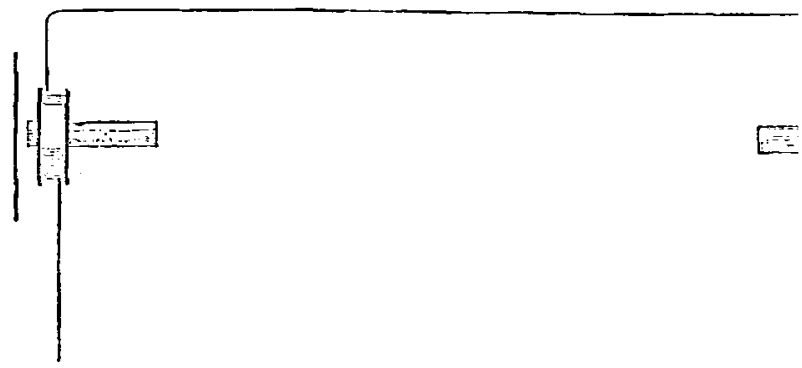

coil. And for erery motion of that picce of iron I can current of electricity. But more than that, the current wi fall in intensity exactly as the iron mores. Hence the , electricity produced in that coil will vary exactly as the that mass of iron. Now suppose that mass of iron to be a liko our parchment drum-head, but of iron; and I speak $t_{1}$ We know that that dise will respond to my roice. What I sound, howerer I vary them in pitch and loudness a that disc will vibrate in number, amplitude and form, exac sive, and currents of electricity will be produced in that will vary exactly in number, strength, and form, with tl ntter. Let this coil be counected with an exactly similar c distince off, and let the currents in the first coil circula the second, then if the second coil surround a mass of soft currents will induco magnetism in tho soft iron, and thos this magnetism will vary exactly with the currents pri If in front of this iron coil we plant an iron dise exactly li one, then every time the iron coil is magnetised it will attr: dise, and will cause it to move. Now the motions of thi vary exactly with the rariation of the magnetism of the magnetisn of the coil will vary exactly with the strer currents producing it. The strength of the currents will $\mathrm{v}$ with the motions of the first dise, and hence the motions of dise will vary exactly with those of the first. In fact they exact reproduction of the first. . Hence with whatever not dise vibrates, howerer much it raries in pitch and lor quality, the second dise reproduces those vibrations exaci vibrations are imparted to the air and thus we have sonnds 
with all the delicate rariations of the human roice. The sc linman voice is transmitted into electric currents, and thes again produce sonorous ribmtions which exactly reproduce roice. Indeed, there is no sound which tho human lips c: or the human ear can detect, which cannot be reproduc telephone, and where it not for practical difficultics, $s$ " mellow to sadness now madden to crime," could be as er mitted from the east to the west as from this hall to the $r$ In fact, to " waft a sigh from Indus to the Pole," is remore poet's dreamland, and has become as much a matter of fa "tracting sunbeams from cucumbers."

But not jet-the rapourings of imaginatice newspa spondents are not yet practical. The articulating telepho an extremely delicate apparatus. It is subject to interferen waif and stray corrent that wanders into a telegrapl wire name is legion. Atmospheric electricity, earth currents a fluence of neigh bouring wires, all generate these troublesoms and interfere rith its action. So that on existing lines of except for short distances, it hus not jet been found use practical, but on short independent isolated lines like tho field telegraphs, it is a thorough practical instrument, ar serving the fullest trial that actual serrice ean gire it.

It works to perfection in mines. There it is not only $\mathrm{f}_{1}$ extrancous troubles, but the silence of the grave facilitate: tion of its "still small roice." It is not eren necessary in : to put it to the ear. Whererer, howerer, extrancous sounc not only is it necessary to put it close to the ear, but to shut out all disturbing elements, two telephones are us cach ear. A bi-aural stethoscope applied to it is also four adjunct. By its means reading is very simple. How far lieard amidst the roar of artillery and the din of battle re: tried.

What it does is this: it transmits to a distance far beyon of the ear, or of the eje, the words of command, the tones a distinct and unmistakable articulation of the general as $w$ private. Such an apparatus must be valuable for military How far it can bo utilized for naral purposes remains Wherever a wire can extend there can the roice be sent mnnicating between the bridge and the wheel, between the the engine room, between the look-ont and the officer of $t$ ought to be useful. For diving operations it is inraluable. operations and range-finding it may prove useful.

But at present it is a mere child. It has startled $u$ novelty, its beauty, and its simplicity. Time alone is cstablish its utility. Probably no instrument that has ever 1 has created more sensation, or has attracted so much at I feel highly honoured in having been allowed to bring br distinguished andience the incomparable invention of Graham Bell.

Major Weatheritead: I should like to ask how it lappens that 
continues so much longer in the case of the bell being struch, than case of the soumd of the roice?

Mr. Preece: The simple reason is, the vibmtions of the bell aro they are not rapidly stopped. When I take a whistle, blow it and $\mathrm{s}$ ceases at once the moment rou remore the souree of the sound. But the bell, as in the case of the glass, the ribration continues. If you glass to sound, you can sce the nusical warelets on the surface of th redJ prettily slow the ribration of the body itself.: There is a loss $o$ telephone howerer at a great distance; ts the distance increases same effect as it would hare upon the roice itself, for when a person and further away, the sounds come gentler and gentler; and in when you add resistance or increase the length of jour line, so the come from a greater and greater distance.

Captain MATSE, R.N.: I should like to ask jou how far the roi whether you hare any idea of being able to communicate in this 1 Atlantic?.

Mr. PreEce: I am not prepared to say that there is much hope across the Atlantic, but I think it possible to talls to distances grc distance across the Atlantic. The reason we cannot talk across $t$ because there is a peculiar electric offect in submarine cable called is as though the elcetricity were absorbed by the gutta-pereha, and smal in at one end nerer, arrive at the other. "They get rolled up as it $\mathrm{mi}$ that on a long submarine cable, instead of getting the finer sounds tions are rapid, they would all come out as one current, not producin all. It does not secm at present practicable to apply to a greater 200 miles, but in the present day that man rould be a rery rash $\mathrm{m}$. affirm that it is impossible to do anytling.

The Cramparax : Te must, I think, think $7[r$. Preece rery much fo ing and able lecture that he has given us ou the Tclephone. There ari gentlemen who have had greater experience in telegraphy than Mr. P member of that departuent to which we all owe so much-the Po Department. I think that none will deny the great adrantages of tho there are few Olicers who are not well aware of its great importance is service. I can hardly speak so much of tho Nary, but $T$ dare say telegraph will also be of great use. There is no doubt that in all lawe been mentioned by Mr. Preece, it will be most raluable. Ther that I think will bear much on its adrantages in the Arms, riz., t] away with a great deal of difficulty in prosiding a suffeient number 0 on serrice. Ficre erery man will be as it were a trained telegraph will be able to speak through the telephone without having receired a in telegraphy. It only remains for scientific gentlemen to perfect th which can only as yet be considered as in its infaney. There lies th we must try experiments and endearour to perfect it as soon as we quite sure that the result will be to the great. adrantnge of our serv name I beg to thank $\mathrm{Mr}$. Prece for his interesting lecture. 
NAJES OF MEIFBERS, who joined the Institution betreen the 1st 31st March, 1878.

\section{LIFE MIFMBERS.}

Trarers, J. A., Capt. York Art. Mrilitia. Pochin, Korman, Lieut. 7th Royal Fusiliers.

Poole, M. C., Capt. Madras S. Corps. Maule, II, B., Major R.A.

Hay, James B., Licut. R.N.

Smith, Walter WV. MI., Lient. R.A.

Barrett, Lennard, Lieut. R.A.

A'Court, Charles, Lieut. Rifle Briga le.

Cowan, Jas. H., Lieut. R.E.
Draffen, W. Pitt; JIajor Mrilitia.

Tomlinson, E. D., II.D., \& A.M.D.

Cooper, Win., Capt. Ii Brigade.

Whitehead, Henry, Lict Rifle Vols.

Gordon, Alerander, Capt drt. Vols.

\section{ANNUAL SUBSCRIBERS.}

Rolph, W. MI., Capt. 17th Regt.

Spicer, IV. J., Ens. Hon. Art. Company. Gordon, WV. L. C., Lient. R.A.

Moutgomery, Sir Robt., G.C.S.I., K.C.B.

Ross of Bladensberg, E., Licut. R.E.

Florence, Henry L., Capt. 40th 3ridds. Rifle Vols.

Dickson, E. T., Licut. 49th Regt.

Warell, L., MIajor Ben. S. Corps.

IIudleston, Wilfred, Lieut.-Col. Mradras. S. Corps.

Butler, John, MLajor 3rd Surrey Rifle Vols.

O'Brien, F. D. J., Licut. West Iínt Mrilitin.

Crowe, Robt., Capt. h.-p., Unatt.

Paton, Geo., M.D., D.-I.-Gen. of Tlospitals.

Tallings, A., Capt. Ben. S. Corps.

Hirst, 'T. B., Capt. 34th West Fork Rifle Vols.

Lawton, F. E. A., Lieut. 3.1th West Iork Rifle Tols.

Prichard, II. C., Iicut 2nd Ion. Rille Vols.

Tyrwhitt, Philip N., Commander R.N.

Drew, George, Lieut.-Col. 1st Lon. Engineer Yols.

Skene, J. G., Arajor 7ith Regt.

Jones, E. V., Capt. 2Sth Midds. Rifle Tols.

Wilkin, W. H., Major 3rd Middx. Art. Tols.
Heath, W. E., Capt. 39tb Tols.

Phillpotts, $\perp$. T., Lieut.-G

Egerton, G. Le C., Lieut.

Beresford-Peirsc, A. do la Regt.

MIXIinn, F. A., Capt. 2n Tols.

Lee, Henry, Capt. 3rd SI Vols.

Garstang, T. IF. II., Cap Rifle Vols.

Strles, R. Osman, Lieut Rifte Tols.

Freeland, John, Capt. 2n Vols.

Robinson, T. Mr., Lieut.-1 Rifle Vols.

De Irodgson, D. F., Mr.D., A.MI.1..

Fing, Walter S., Licut. I

Pitman, William, Capt. :

IFasterman, John, Lieut.

Parkinson, R. II., Licut.

Gladstone, C. E., Lieut. :

Gres, Harrs G., Licut. ]

Chesne, W. R., Capt. 41 Vols.

Rolfe, Robt., Capt. 39t Vols.

Colomb, Geo. II., Col. R

Baruett, H. C. B., Ise S. Corps. 
Kingseote, Anthon, Lieut. R.N.

Torrs, H. J. B., Lieut. Rojal Lon. Mílitia.

Fitzgeraldy O. J. O., Major Madras S. Corps.

Philipps, c. E. G., Lient. Pembroke Yeo. Car.

Lee, Eliis, Capt. 65th Regt.

Creswick, Nath., Lieut.-Col. 4th West York Art. Vols.

Lambert, Geo., Licut. 22nd Middx. Rifle Tols.

Lambert, II. C., Lieut. 22nd Middr. Rifle Vols.

Hutton. Herbert, Capt. 4th West York Art. Vols.

Wire, Travers B., Capt. 1st Surrey Rifle Vols.

Fergusson, J. A., Lieut. Rifle Brigade.

Vauglan, Henry, Commander R.N.

Silk, O. Alex., Lieut. 1st Fent Art. Vols.

Fryer, G. W. S., Lieut. 1st Warwick Mrilitia.

Wadmore, A. H. T., Capt. 11th Middr. Rifle Yols.

Monckton, E. P., Capt. Northam and Rutland Militia.

Andrex, C. W., Capt. lato 19th Surrey Rifle Vols.

Custance, R. N., Lieut. R.N.

Rason, E. G., Lieut. R.N.

Sandes, H. T. T., Capt. R.A.

Cole, W. U., Lieut. 3rd Dragoon Guards.
Woodman, L. J., Capt. 3rd Lon. Vols.

Gambier, J. W., Commander R.N IIolland, G. E., Lieut. Lon. Brigade.

Kinder, Ernest, Lieut. R.N.

Iill, F. C., Lieut. Col. 56th Regt.

Pott, Norbury, Major 1st Surre. Vols.

Colvile, F. M., C.B., Col. 21st I Depôt.

Fellowes, James, Capt. R.E.

O'Neil, Geo. A., Lieut. 8th Lanc Vols.

Welch, F., Capt. 25th Regt.

Bray, Norman A., Lieut. 27th Re

Gleather, W. B. G., Major 47th 1

IIelme, G. C., Capt. 10th Regt.

Ford, William W., Licut. 23rd : Rifle Vols.

Kerby, William, Licut. 7th C Rifle Tols.

Purchas, J. R. P., Lieut. 40th Re

Long, C. J., Lieut. R.H.A.

Bell, R., Lieut. 56th Regt.

McClintock, W. G. W., Lieut Regt.

Hills, John, Lieut.-Col. R.E.

Bushby, J. William, Lieut.-Col. ( Westminster Rifle Vols.

Pocklington - Coltman, R., Maj Middx. Engineer Yols.

Stephens, J. N., Lieut. 1st Surr Yols. 